\title{
Increase in Air Temperature in The Region of South Sumatra Province as The Indicator of Global Warming and The Effect on Transpiration of Lansium domesticum Corr.
}

\author{
Ari Sugiarto, Hanifa Marisa, and Sarno \\ Department of Biology, Faculty of Mathematics and Natural Sciences, Sriwijaya University
}

\begin{abstract}
Global warming is one of biggest problems faced in the $21^{\text {st }}$ century. One of the impacts of global warming is that it can affect the transpiration rate of plants that occur. This study purpose to see how much increase in air temperature that occurred in the region of South Sumatra Province and to know the effect of increase in ari temperature in the region of South Sumatra Province on transpiration rate of Lansium domesticum Corr. This study used a complete randomized design with 9 treatments $\left(22.9{ }^{\circ} \mathrm{C}, 23.6{ }^{\circ} \mathrm{C}, 24.6{ }^{\circ} \mathrm{C}, 26.3{ }^{\circ} \mathrm{C}, 27{ }^{\circ} \mathrm{C}, 27.8^{\circ} \mathrm{C}\right.$, $31.7{ }^{\circ} \mathrm{C}, 32.5^{\circ} \mathrm{C}$, and $32.9^{\circ} \mathrm{C}$ ) and 3 replications. Air temperature data as secondary data obtained from the Meteorology, Climatology and Geophysics Agency (MCGA) Palembang Climatology Station in South Sumatra Province. The measurement of transpiration rate is done by modified potometer method with additional glass box. The data obtained are presented in the form of tables and graphs. Transpiration rate $\left(\mathrm{mm}^{3} / \mathrm{g}\right.$ plant/ hour $)$ at temperture $22.9^{\circ} \mathrm{C}=4.37,23.6^{\circ} \mathrm{C}=7.03,24.6{ }^{\circ} \mathrm{C}=8.03,26.3{ }^{\circ} \mathrm{C}=10.11,27{ }^{\circ} \mathrm{C}=13.13,27.8{ }^{\circ} \mathrm{C}=17.87,31.7$ ${ }^{\circ} \mathrm{C}=23.21,32.5^{\circ} \mathrm{C}=25.45$ and $32.9^{\circ} \mathrm{C}=27.24$. At the minimum air temperature in the region of South Sumatra Province there is increase in air temperature of $1.5{ }^{\circ} \mathrm{C}$, average daily air temperature increase $1.3{ }^{\circ} \mathrm{C}$ and maximum air temperature increase $1.2^{\circ} \mathrm{C}$.
\end{abstract}

Keywords: Global warming, Air temperature, South Sumatra, Transpiration Rate , Lansium domesticum Corr.

\section{INTRODUCTION}

Global warming is one of biggest problems faced in the $21^{\text {st }}$ century. Various problems a rise from the effects of global warming. Global warming is impact of greenhouse effect. Global warming it self can be regarded as an increase in average temperature of the Earth's surface within a certain period of time caused by greenhouse effect. [1]. The rise in global earth temperature or commonly known as global warming is one example of what is called climate change.

Most environmental experts agree that climate change is one of effects of global warming. Increase in greenhouse gas concentrations, especially carbon dioxide $\left(\mathrm{CO}_{2}\right)$, methane $\left(\mathrm{CH}_{4}\right)$, dinitric oxide $\left(\mathrm{N}_{2} \mathrm{O}\right)$, perfluorocarbon (PFC), hydrofluorocarbon (HFC), and sulfur hexafluoride $\left(\mathrm{SF}_{6}\right)$ in the Earth's atmosphere are believed to be the cause of global warming [2].

The region of South Sumatera Province is dominated by wetlands that hold a lot of carbon stocks, but as development progresses there is a lot of change in transfer of this wetland function which causes stored carbon to be released into atmosphere. Carbon is one of causes of greenhouse effect. Number of industries and vehicles in the area of South Sumatra Province quite a lot, these industries and vehicles use fossil fuels that do not directly contribute to emissions gas from operating activities.

It is not impossible that global warming has also occurred in the region of South Sumatra Province to see potential of large greenhouse gases. One of the things that can be done to see if there has been golabal warming in the region of South Sumatra Province by examining the temperature in the last few decades in order to see increase in temperature that occurred. Increase in air temperature is an indicator of the occurrence of global warming. The impact of global warming is expected to affect transpiration of plants. Transpiration of plants is influenced by $\mathrm{CO}_{2}$, light, temperature, air flow, moisture and ground water availability [3]. Increase in temperatures will lead to increased transpiration of plants [4].

One of plants estimated to be affected by global warming in South Sumatera Province is Lansium domesticum Corr., L. domesticum is one of many plants that grow in South Sumatra Province and also one of the leading plants of fruits, even outside the South Sumatra Province L. domesticum is considered typical fruits of the South Sumatra.

Seeing impact of global warming which one of them led to increase in transpiration rate of plants. It is necessary to conduct an assessment of temperature in the South Sumatra Province in last few decades to see increasing in temperature that occurs as an indicator of global warming and 
impact of global warming on L. domesticum transpiration rate.

\section{RESEARCH METHODS}

\section{Time and Place}

The research was conducted in February to March 2018. Located in Serdang Menang Village, Sirah Pulau Padang Sub-district, Ogan Komering Ilir District, South Sumatera Province and Plant Physiology Laboratory, Department of Biology, Faculty of Mathematics and Natural Sciences, Sriwijaya University.

\section{Research Design}

The study used a completely randomized design with 9 treatments and 3 replications. Treatment:

1. minimum temperature in $1977\left(22,9^{\circ} \mathrm{C}\right)$

2. minimum temperature in $1997\left(23,6^{\circ} \mathrm{C}\right)$

3. minimum temperature in $2017\left(24,4^{\circ} \mathrm{C}\right)$

4. daily average temperature in $1977\left(26,3^{\circ} \mathrm{C}\right)$

5. daily average temperature in $1997\left(27^{\circ} \mathrm{C}\right)$

6. daily average temperature in $2017\left(27,5^{\circ} \mathrm{C}\right)$

7. maximum temperature in $1977\left(31,7^{\circ} \mathrm{C}\right)$

8. maximum temperature in $1997\left(32,5^{\circ} \mathrm{C}\right)$

9. maximum temperature in $2017\left(32,9^{\circ} \mathrm{C}\right)$

Year 1977 was year of preliminary air temperature data studied, 1997 was year of mid air temperature data studied, and year 2017 was year of final air temperature data studied. Analysis of Variant (ANOVA) 5\% is used to determine the level of error in the research conducted.

\section{Work Procedures}

Air temperature assessment in the region of South Sumatra Province in the last few decades

The collection of secondary air temperature data in the region of South Sumatra Province during last few decades is obtained from the Meteorology, Climatology and Geophysics Agency (MCGA) Palembang Climatology Station in the South Sumatra Province which is accessed online at https://dataonline.bmkg.go.id. The data that has been obtained, then searched the average temperature (minimum, maximum, and daily average) per year. The data obtained is presented in the form of a line graph.

Transpiration Measurement of Lansium domesticum Corr.

This transpiration measurement used the modified Potometer method with an additional glass box (Fig. 1). This transpiration measurement uses $L$. domesticum seedlings. L. domesticum seedlings used have criteria of number of leaves, height, and weight of plants are almost the same.
Seedlings used are estimated to be about 2 year old. The data obtained are presented in table.

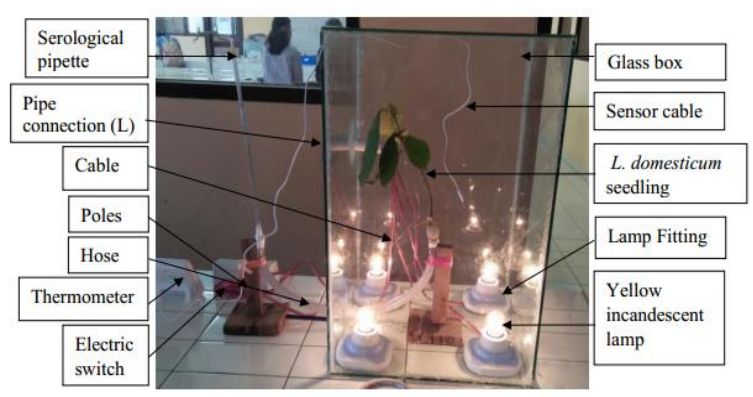

Fig. 1 Schematic of experimental tool

\section{Data Analysis}

Transpiration rate (TR) using the potometer method is calculated by a simple formula [5]: Transpiration rate (TR):

Bubble travel length $(\mathrm{mm}) \mathrm{X}$ Area of hose hole

With units of $\mathrm{mm}^{3} / \mathrm{g}$ plant / hour

From this formula can be adapted to the research method used to be:

Transpiration rate $(\mathrm{TR})$ :

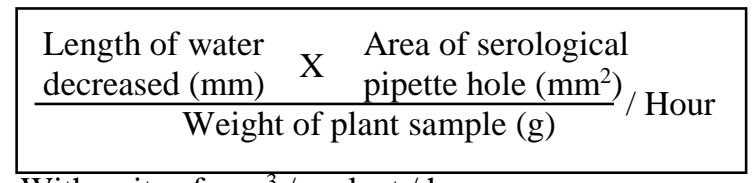

With units of $\mathrm{mm}^{3} / \mathrm{g}$ plant / hour

Number of water evaporation:

Initial water limit on serological pipette - Water end limit on serologis pipette

With units of $\mathrm{ml}$

The data has been processed presented in table form using microsoft word software. Existing data in table form is processed with SPSS statistical analysis software.

\section{RESULTS AND DISCUSSION}

\section{Air Temperature Assessment in The Region of South Sumatra Province in The Last Few Decades}

The graph of air temperature study in the South Sumatera Province from 1997 to 2017 can be seen in Fig 2. 


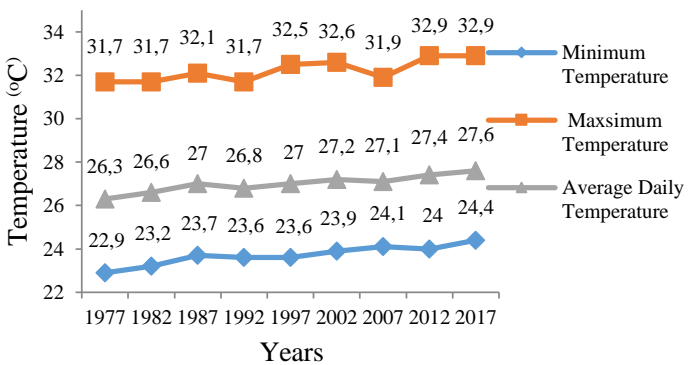

Fig. 2 Graph of average air temperature in the region of South Sumatra Province in 19772017

The minimum air temperature in the region of South Sumatra Province in 1977 is $22.9{ }^{\circ} \mathrm{C}$ and the minimum air temperature in 2017 in the area of South Sumatra Province is $24.4{ }^{\circ} \mathrm{C}$, increase in air temperature that occurred at $1,5^{\circ} \mathrm{C}$. In 1977 the average daily air temperature is $26.3{ }^{\circ} \mathrm{C}$ and the average daily air temperature in 2017 is $27.6{ }^{\circ} \mathrm{C}$, an increase in air temperature that occurred at $1,3{ }^{\circ} \mathrm{C}$. In 1977 the maximum air temperature is $31.7^{\circ} \mathrm{C}$ and the maximum air temperature in 2017 is 32.9 ${ }^{\circ} \mathrm{C}$, an increase in temperature that occurred at 1.2 ${ }^{\circ} \mathrm{C}$.

Has seen an increase in air temperature in the region of South Sumatra Province be it the minimum air temperature within the last 4 decades, average air temperature, and maximum air temperature. Increase in air temperature can be indicates that the occurrence of global warming in the region of South Sumatra Province, it can be inferred from the definition of global warming that is increase in average temperature of the Earth surface within a certain time range.

Thermometers data for 150 years ago or similar documents show that global temperature rise reached $1{ }^{\circ} \mathrm{C}$ from preindustrial periods. These estimates suggest that even the most aggressive mitigation efforts may lead warming to $2{ }^{\circ} \mathrm{C}$ and a lack of mitigation efforts causing warming to $3{ }^{\circ} \mathrm{C}$ or even more than $5^{\circ} \mathrm{C}[6]$.

Increased temperature in the region of South Sumatra Province within the last 4 decades of air fluctuations has increased. Vegetation plays an important role in the fluctuation of increased temperature in the region of South Sumatra Province. Presence of vegetation in areas that contribute greenhouse gas emissions as in the city, this will help in lowering the amount of greenhouse gases in atmosphere. [7] Woody plant absorbs $\mathrm{CO}_{2}$ from the air and is stored in the body of the plant (biomass) in form of carbon (C).

Urban forest is used to resist the occurrence of urban heat islands through heat convection process by utilizing insulating properties and calorific capacity of anatomical structure system of trees and soils [8].
In addition to vegetation factor, it causes fluctuation of increase in air temperature in the region of South Sumatera Province that is mitigation efforts of global warming in the region of South Sumatera Province and the influence of different dry season and rainy season every year. Mitigation effort undertaken aims to reduce amount of greenhouse gases in atmosphere that are expected to reduce air temperature in the area of South Sumatra Province.

The South Sumatra greenhouse gas emissions will increasing from about 2 million tonnes of $\mathrm{CO}_{2}$ equivalent in 2010 to about 3.5 million to equivalent $\mathrm{CO}_{2}$ by 2020 . The target of $10.16 \%$ reduction in all sectors by 2020 is outlined in the Plan Regional Action of Greenhouse Gas Emission Reduction in South Sumatra. Forms of mitigation undertaken are agricultural management and increased food security, environmental management, forestry and peatland management, improving public health through waste and waste management [9].

El nino symptoms in Indonesia in a given year is also one of factors causing increase in air temperature in the region of South Sumatra Province occurred fluctuate. Occurrence of El nino is usually followed by decreased rainfall and increasing air temperature [10]. El Nino phenomenon from 1975 to 1980 was classified as weak, 1980 to 1985 classified as strong category, from 1985 to 1995 classified as moderate, 1995 to 2000 classified as strong, and year 2000 to 2015 are classified as moderate. El Niño phenomenon with strongest intensity level occurred in 1997 and 1998 [11].

\section{Transpiration Measurement of Lansium domesticum Corr.}

Table 1. Effect of increase in air temperature in the South Sumatera Province on average transpiration rate $\left(\mathrm{mm}^{3} / \mathrm{g}\right.$ plant / hour $)$ of Lancium domesticum Corr.

\begin{tabular}{ccc}
\hline Treatment & Temperature & $\begin{array}{c}\text { Average transpiration } \\
\text { rate }\end{array}$ \\
\hline 1 & $22,9^{\circ} \mathrm{C}$ & 4,37 \\
2 & $23,6^{\circ} \mathrm{C}$ & 7,03 \\
3 & $24,4^{\circ} \mathrm{C}$ & 8,03 \\
4 & $26,3^{\circ} \mathrm{C}$ & 10,11 \\
5 & $27^{\circ} \mathrm{C}$ & 13,13 \\
6 & $27,5^{\circ} \mathrm{C}$ & 17,87 \\
7 & $31,7{ }^{\circ} \mathrm{C}$ & 23,21 \\
8 & $32,5^{\circ} \mathrm{C}$ & 25,45 \\
9 & $32,9^{\circ} \mathrm{C}$ & 27,24 \\
\hline
\end{tabular}

Average transpiration rate of L.domesticum at treatment 1 is $4.37 \mathrm{~mm}^{3} / \mathrm{g}$ plant/hour. At treatment 2 average transpiration rate is $7.03 \mathrm{~mm}^{3} / \mathrm{g}$ plant/ hour. At treatment 3 average transpiration rate is 
$8.03 \mathrm{~mm}^{3} / \mathrm{g}$ plant/hour. At treatment 4 average transpiration rate is $10.11 \mathrm{~mm}^{3} / \mathrm{g}$ plant/hour. At treatment 5 average transpiration rate is $13.13 \mathrm{~mm}^{3} /$ g plant/hour. At treatment 6 average transpiration rate is $17.87 \mathrm{~mm}^{3} / \mathrm{g}$ plant/hour. At treatment 7 average transpiration rate is $23.21 \mathrm{~mm}^{3} / \mathrm{g}$ plant/ hour. At treatment 8 average transpiration rate is $25.45 \mathrm{~mm}^{3} / \mathrm{g}$ plant/hour and At treatment 9 average transpiration rate is $27.24 \mathrm{~mm}^{3} / \mathrm{g}$ plant/hour.

Above data shows that the increase in minimum air temperature in 1977-2017 led to an increase in transpiration rate is $3.66 \mathrm{~mm}^{3} / \mathrm{g}$ plants/hour. Increase in daily average air temperature in 19772017 led to an increase in transpiration rate is 7.76 $\mathrm{mm}^{3} / \mathrm{g}$ plant/hour. Increase in maximum air temperature in 1977-2017 led to an increase in transpiration rate is $4.03 \mathrm{~mm}^{3} / \mathrm{g}$ plant/hour. Analysis of Variance (ANOVA) 5\% show value of F count (202.120) > F table (2.51)

From the data in Table 1 , it is clear that global warming has an impact on increase in transpiration rate of $L$. domesticum. This increase in transpiration rate can certainly disrupt survival of L.domesticum, this will make L.domesticum need more water to cooling body temperature from impact of global warming that causes increase in air temperature within a certain time range.

Table 2 Effect of increase in air temperature in the South Sumatera Province on averange water evaporation (ml) of Lancium domesticum Corr.

\begin{tabular}{ccc}
\hline Treatment & Temperature & $\begin{array}{c}\text { Average Water } \\
\text { Evaporation }\end{array}$ \\
\hline 1 & $22,9^{\circ} \mathrm{C}$ & 0,013 \\
2 & $23,6^{\circ} \mathrm{C}$ & 0,02 \\
3 & $24,4^{\circ} \mathrm{C}$ & 0,023 \\
4 & $26,3^{\circ} \mathrm{C}$ & 0,04 \\
5 & $27^{\circ} \mathrm{C}$ & 0,043 \\
6 & $27,5^{\circ} \mathrm{C}$ & 0,053 \\
7 & $31,7^{\circ} \mathrm{C}$ & 0,08 \\
8 & $32,5^{\circ} \mathrm{C}$ & 0,087 \\
9 & $32,9^{\circ} \mathrm{C}$ & 0,07 \\
\hline
\end{tabular}

Average evaporation of water occurring in transpiration measurements of L.domesticum can be seen in Table 2. At treatment 1 average number of water evaporation through transpiration occurred is $0.013 \mathrm{ml}$. At treatment 2 average number of water evaporation is $0,02 \mathrm{ml}$. At treatment 3 average number of water evaporation is $0.023 \mathrm{ml}$. At treatment 4 average number of water evaporation is $0.04 \mathrm{ml}$. At treatment 5 average number of water evaporation is $0.043 \mathrm{ml}$. At treatment 6 average number of water evaporation is $0.053 \mathrm{ml}$. At treatment 7 average number of water evaporation is $0.08 \mathrm{ml}$. At treatment 8 average number of water evaporation is 0.087 and at treatment 9 average number of water evaporation is $0.07 \mathrm{ml}$.

Table 3 Average light intensity (Lux) in transpiration measurement of Lancium domesticum Corr.

\begin{tabular}{ccc}
\hline Treatment & Temperature & $\begin{array}{c}\text { Average Light } \\
\text { Intensity }\end{array}$ \\
\hline 1 & $22,9^{\circ} \mathrm{C}$ & 3,67 \\
2 & $23,6^{\circ} \mathrm{C}$ & 9,33 \\
3 & $24,4^{\circ} \mathrm{C}$ & 5,67 \\
4 & $26,3^{\circ} \mathrm{C}$ & 293,33 \\
5 & $27{ }^{\circ} \mathrm{C}$ & 322,67 \\
6 & $27,5^{\circ} \mathrm{C}$ & 379,00 \\
7 & $31,7^{\circ} \mathrm{C}$ & 647,00 \\
8 & $32,5^{\circ} \mathrm{C}$ & 324,33 \\
9 & $32,9^{\circ} \mathrm{C}$ & 513,33 \\
\hline
\end{tabular}

Average light intensity in transpiration measurement of $L$. domesticum. can be seen in Table 3. At treatment 1 average intensity is 3.67 lux. At treatment 2 average light intensity is 9.33 lux. At treatment 3 average light intensity is 5.67 lux. At treatment 4 average light intensity is 293.33 lux. At treatment 5 average light intensity is 322.67 lux. At treatment 6 average light intensity is 379 lux. At treatment 7 average light intensity is 647.00 lux. At treatment 8 average light intensity is 324.33 lux and at treatment 9 average light intensity of 513.33 lux.

Table 4 Average air humidity (\%) in transpiration measurements of Lancium domesticum Corr.

\begin{tabular}{ccc}
\hline Treatment & Temperature & $\begin{array}{c}\text { Average Air } \\
\text { Humidity }\end{array}$ \\
\hline 1 & $22,9^{\circ} \mathrm{C}$ & 86,00 \\
2 & $23,6^{\circ} \mathrm{C}$ & 84,67 \\
3 & $24,4^{\circ} \mathrm{C}$ & 86,67 \\
4 & $26,3^{\circ} \mathrm{C}$ & 90,67 \\
5 & $27^{\circ} \mathrm{C}$ & 86,67 \\
6 & $27,5^{\circ} \mathrm{C}$ & 84,33 \\
7 & $31,7^{\circ} \mathrm{C}$ & 81,33 \\
8 & $32,5^{\circ} \mathrm{C}$ & 78,67 \\
9 & $32,9^{\circ} \mathrm{C}$ & 78,00 \\
\hline
\end{tabular}

Average air humidity in transpiration measurements of $L$. domesticum can be seen in Table 4. At treatment 1 average air humidity is $86.00 \%$. At treatment 2 average air humidity is $84.67 \%$. At treatment 3 average air humidity is $86.67 \%$. At treatment 4 average air humidity is $90.67 \%$. At treatment 5 average air humidity is $86.67 \%$. At treatment 6 average air humidity is $84.33 \%$. At treatment 7 average air humidity is $81.33 \%$. At treatment 8 average air humidity is 
$78.67 \%$ and at treatment 9 average air humidity is $78.00 \%$.

Table 5 Average length $(\mathrm{cm})$, width $(\mathrm{cm})$ and number of leaf samples used in transpiration measurements Lancium domesticum Corr.

\begin{tabular}{ccccc}
\hline Treatment & Temperature & $\mathrm{L}$ & $\mathrm{W}$ & $\mathrm{N}$ \\
\hline 1 & $22,9^{\circ} \mathrm{C}$ & 11,64 & 5,30 & 7,33 \\
2 & $23,6^{\circ} \mathrm{C}$ & 10,78 & 5,23 & 7,67 \\
3 & $24,4^{\circ} \mathrm{C}$ & 11,16 & 5,25 & 7,33 \\
4 & $26,3^{\circ} \mathrm{C}$ & 12,06 & 5,64 & 7,33 \\
5 & $27{ }^{\circ} \mathrm{C}$ & 11,87 & 5,55 & 7,67 \\
6 & $27,5^{\circ} \mathrm{C}$ & 11,44 & 5,11 & 8,00 \\
7 & $31,7^{\circ} \mathrm{C}$ & 12,75 & 5,83 & 8,00 \\
8 & $32,5^{\circ} \mathrm{C}$ & 11,18 & 5,24 & 8,00 \\
9 & $32,9^{\circ} \mathrm{C}$ & 10,62 & 5,06 & 7,67 \\
\hline
\end{tabular}

L: Average leaf length $(\mathrm{cm})$

$\mathrm{W}$ : Average eaf width $(\mathrm{cm})$

$\mathrm{N}$ : Average number of leaves

Average length, width, and number of L. domesticum leaf seedlings used in transpiration measurements can be seen in Table 5. Average length of $L$. domesticum seedlings used in transpiration measurements ranged from 10,62 $12,75 \mathrm{~cm}$, the average leaflet width $L$. domesticum used in the measurement of transpiration 5.06 - 5,83 $\mathrm{cm}$. The average number of $L$. domesticum seedlings used in transpiration measurements was 7,33 - 8 leaves.

Table 6 Average weight $(\mathrm{g})$ and height $(\mathrm{cm})$ of samples used in transpiration measurements of Lancium domesticum Corr..

\begin{tabular}{cccc}
\hline Treatment & Temperature & $\begin{array}{c}\text { Average } \\
\text { weight }\end{array}$ & $\begin{array}{c}\text { Average } \\
\text { height }\end{array}$ \\
\hline 1 & $22,9^{\circ} \mathrm{C}$ & 8,96 & 41,63 \\
2 & $23,6^{\circ} \mathrm{C}$ & 7,83 & 41,40 \\
3 & $24,4^{\circ} \mathrm{C}$ & 8,70 & 38,33 \\
4 & $26,3^{\circ} \mathrm{C}$ & 10,40 & 44,13 \\
5 & $27^{\circ} \mathrm{C}$ & 8,70 & 44,90 \\
6 & $27,5^{\circ} \mathrm{C}$ & 8,63 & 45,23 \\
7 & $31,7^{\circ} \mathrm{C}$ & 10,13 & 48,10 \\
8 & $32,5^{\circ} \mathrm{C}$ & 9,90 & 43,07 \\
9 & $32,9^{\circ} \mathrm{C}$ & 7,40 & 40,87 \\
\hline
\end{tabular}

Average weight and height data of L. domesticum seedlings used in transpiration measurements can be seen in Table 6. Average weight of $L$. domesticum seedlings used in transpiration measurements ranged from 7.40 $10.40 \mathrm{~g}$ and mean high sample $L$. domesticum used in transpiration measurements ranged from 38.33 -
$48.10 \mathrm{~cm}$. Measurement of plant height is measured from tip of root to end of stem.

Seeds weight, leaf length, leaf width, number of leaves, light intensity, and air humidity also affect $\mathrm{t}$ large and small transpiration rate of L.domesticum. Transpiration of plants is influenced by $\mathrm{CO}_{2}$, light, temperature, airflow, moisture and ground water availability [3]. Increasingd temperatures will lead to increasingd transpiration of plants [4].

Duku plants can flourish in areas with an average temperature of $19^{\circ} \mathrm{C}$ with a $\mathrm{pH}$ value of 6 to 7 [12]. Good air temperature for shoots growth ranges from $19{ }^{\circ} \mathrm{C}$ to $24{ }^{\circ} \mathrm{C}$ [13]. Duku plants can grow optimally in areas with low wind speed, high rainfall (1500-2500 mm / year), high humidity, high intensity of sunlight, no waterlogging, and a height of no more than $650 \mathrm{mdpl}$ [14]. Productivity of duku plants is influenced by the texture of the soil and its nutrient content [15].

\section{CONCLUSION}

At minimum air temperature in the South Sumatera Province there is an increase in air temperature of $1.5{ }^{\circ} \mathrm{C}$ which causes the increase in transpiration rate of $L$. domesticum is $3.66 \mathrm{~mm}^{3} / \mathrm{g}$ plant/hour. For the average daily air temperature there was an increase in air temperature is 1.3 which causes the increase in transpiration rate of L. domesticum is $7.76 \mathrm{~mm}^{3} / \mathrm{g}$ plant/hour and increase in maximum air temperature is $1.2{ }^{\circ} \mathrm{C}$ which causes increase in transpiration rate of L. domesticum is $4.03 \mathrm{~mm}^{3} / \mathrm{g}$ plant/hour.

\section{REFERENCES}

[1] Bayong T. H. K., Iklim dan Lingkungan, Bandung, PT Cendekia Jaya Utama, 1987 ,dalam, Suwedi N., Upaya Pencegahan dan Penanggulangan Dampak Pemanasan Global. J. Teknologi Lingkungan, Vol. 6, Issue . 2, 2005, pp.397-401.

[2] Sugiyono A., Penanggulangan Pemanasan Global di Sektor Penggunaan Energi. J. Sains \& Teknologi Modifikasi Cuaca, Vol. 7, Issue. 2, 2006, pp. 15-19.

[3] Abercrombie M., M. Hickman, M. L. Johnson, and M. Thain., Kamus Lengkap Biologi, Diterjemhkan oleh, Sutarmi T. S dan Nawangsari S., Jakarta, Erlangga, 1993, Edisi ke 8 .

[4] Setiawan E., Perkembangan Tanaman, Madura, Universitas Trunojoyo Madura Press, 2015, pp. 1-111.

[5] Nurwahyuni I., Riyanto S., and Elimasni., Fisiologi Tumbuhan; Transpirasi, (online), http://ocw.usu.ac.id/course/detail/biologi$\underline{\text { s1/8110000036-fisiologi-tumbuhan.html, }}$ 
2009, dikases pada tanggal 19 September 2017.

[6] World Development Report 2010, Laporan Pembangunan Dunia 2010; Pembangunan dan Perubahan Iklim, Diterjemahkan oleh, Sungkono C., Jakarta, Salemba Empat, 2010, pp. 476.

[7] Supriadi H., Peran Tanaman Karet Dalam Mitigasi Perubahan Iklim, Buletin RISTRI, Vol. 3, Issue. 1, 2012, pp. 79-90.

[8] Sangkertadi and Reny S., Upaya Peredaman Laju Peningkatan Suhu Udara Perkotaan Melalui Optimasi Penghijauan, EKOTON, Vol. 8, Issue. 2, 2008, pp. 41-48.

[9] Pengarusutamaan Isu Perubahan Iklim ke Dalam RPJMD Provinsi Sumatera Selatan 2014 - 2018, Jakarta, Japan International Cooperation Agency Project of Capacity Development of Climate Change in Indonesia, 2014, pp. 1-40.

[10] Irawan B., Fenomena Anomali Iklim El Nino dan La Nina: Kecendrungan Jangka Panjang dan Pengaruhnya Terhadap Produksi Pangan, Forum Penelitian Agro Ekonomi, Vol. 24, Issue. 1, 2006, pp. 28-45.

[11] Badan Meteorologi, Klimatologi dan Geofisika (BMKG), Press Release Kekeringan 2015.2 (Online). http://data.bmkg.go.id>elnino_2015_KBMK,

[12] Prihatman K., Duku (Lansium domesticum Corr.), Jakarta, Kantor Deputi Menegristek Bidang Pendayagunaan dan Pemasyarakatan Ilmu Pengetahuan dan Teknologi, 2000, pp.113.

[13] Lizawati., Budiyathi I., Gusniwati., Neliyati., and M. Zuhdi.,. Fenologi Pertumbuhan Vegetatif Dan Generatif Tanaman Duku Varietas Kumpeh Pada Berbagai Umur, Program Studi Agroekoteknologi, Fakultas Pertanian Universitas Jambi, Vol. 2, Issue. 1, 2013, pp.16-26.

[14] Mayanti T., Kandungan Kimia dan Bioaktivitas Tanaman Duku, Bandung, Universitas Padjadjaran Press, 2009, pp.1-119.

[15] Salim M., Yahya., Hotnida S., Tanwirotun N., and Marini., Hubungan Kandungan Hara Tanah Dengan Produksi Senyawa Metabolit Sekunder Pada Tanaman Duku (Lansium domesticum Corr var Duku) dan Potensinya Sebagai Larvasida, J. Vektor Penyakit, Vol. 10, Issue. 1, 2016, pp. 11-18. 